\title{
ASAS KEADILAN DALAM SUPLAI MAKAN TAHANAN KEPOLISIAN DAN LEMBAGA PEMASYARAKATAN DIHUBUNGKAN DENGAN UNDANG-UNDANG NOMOR 36 TAHUN 2009
}

\section{THE PRINCIPLE OF FAIRNESS IN THE SUPPLY OF FOOD FOR POLICE PRISONERS AND CORRECTIONAL INSTITUTION ASSOCIATED WITH LAW NUMBER 36 OF 2009}

\author{
Danang Wijayanto, Martin
} Roestamy, Endeh Suhartini

\author{
Program Studi Hukum, Sekolah Pascasarjana, \\ Universitas Djuanda Bogor. \\ Korespondensi : Danang Wijayanto, Telp. - \\ e-mail : danang.wijayanto@unida.ac.id
}

\begin{abstract}
Jurnal Living Law, Vol. 12, No.

1 , 2020

hlm. 1-17

Abstract : This study aims to find out and analyze the mechanism of procurement of food supplies, and the achievement of justice for prisoners of the Police and Penitentiary. The research method used in this study is normative juridical research. The results of this study are: 1) The mechanism of procurement of prisoner food supplies Police and Penitentiary, has sought to fulfill the right of prisoners to food in accordance with applicable standards and also Minister of Law and Human Rights regulations Number M.HH-01.PK.07.02 of 2009. This can be seen from timely food supply and is served three times a day by the Police and Penitentiary even though the menu presented is less varied when viewed from nutritional adequacy figures due to budget constraints, 2) Procurement of goods and services in the field of eating food of police and Penitentiary detainees to achieve justice, the authority of the Budget User Authority (KPA) during the process of auctioning prisoner food ingredients. So based on its authority, KPA has used its authority during the process of auctioning prisoner food ingredients, the legal arrangements for delays in obtaining prisoner food suppliers in the following fiscal year have no clear legal instruments so KPA has taken its own initiative in procuring prisoner food ingredients.
\end{abstract}

Keywords : Inmate; the principle of justice.

Abstrak : Penelitian ini bertujuan untuk mengetahui dan menganalisis mekanisme pengadaan suplai makan, serta tercapainya keadilan bagi tahanan Kepolisian dan Lembaga Pemasyarakatan. Metode penelitian yang digunakan dalam penelitian ini adalah penelitian yuridis normatif. Hasil dari penelitian ini yaitu: 1) Mekanisme pengadaan suplai makan tahanan Kepolisian dan Lembaga Pemasyarakatan, telah berupaya memenuhi hak tahanan akan makanan sesuai peraturan standar yang berlaku dan PermenkumHAM Nomor M.HH-01.PK.07.02 Tahun 2009. Hal ini dapat terlihat dari penyediaan makanan yang tepat waktu dan disajikan tiga kali sehari oleh Kepolisian dan Lembaga Pemasyarakatan walaupun dengan menu yang disajikan kurang bervariasi bila dilihat dari angka kecukupan gizi karena keterbatasan anggaran, 2) Pengadaan barang dan jasa di bidang makan tahanan Kepolisian dan Lembaga Pemasyarakatan untuk tercapainya keadilan adalah kewenangan Kuasa Pengguna Anggaran (KPA) pada saat proses pelelangan bahan makanan tahanan. Berdasarkan kewenangannya maka KPA telah memanfaatkan kewenangannya pada saat proses pelelangan bahan makanan tahanan dilaksanakan, pengaturan hukum untuk keterlambatan saat memperoleh penyedia bahan makanan tahanan pada tahun anggaran berikutnya belum ada instrumen hukum yang jelas sehingga KPA melakukan inisiatif sendiri dalam pengadaan bahan makanan tahanan.

Kata Kunci : Asas Keadilan; Suplai Makanan; Tahanan. 


\section{PENDAHULUAN}

Pasal 1 ayat (1) Undang-undang Dasar Negara Republik Indonesia Tahun 1945 menentukan secara tegas menyebutkan bahwa Negara Indonesia adalah Negara Hukum. Sejalan dengan ketentuan tersebut maka salah satu prinsip terpenting Negara Hukum adalah adanya jaminan kesederajatan bagi setiap orang di hadapan hukum (Equality Before The Law). Oleh karena itu setiap orang berhak atas pengakuan, jaminan, perlindungan dan kepastian hukum yang adil serta perlakuan yang sama di hadapan hukum.

Pemidanaan atau penjatuhan pidana terhadap seseorang yang terbukti melakukan tindak pidana bukanlah sematamata bertujuan untuk pembalasan terhadap perbuatan yang dilakukannya. Pidana penjara merupakan salah satu jenis sanksi pidana yang paling sering digunakan dalam menanggulangi masalah kejahatan. ${ }^{1}$

Penegakan hukum terhadap kejahatan di Indonesia, khususnya dalam hal pemidanaan, seharusnya merujuk pada pendekatan norma hukum yang bersifat menghukum penjahat sehingga dapat memberikan efek jera. Hal ini memberikan wacana kepada para hakim dalam merumuskan vonis penjatuhan sanksi kepada para pelaku kejahatan agar mampu menangkap aspirasi keadilan masyarakat. Kenyataan empiris di bidang pemidanaan secara umum masih menganut pemahaman untuk memperbaiki terpidana di lembaga pemasyarakatan, sehingga memberikan gambaran bahwa kejahatan tersebut hanya terhenti sesaat dan akan muncul kembali dalam lingkungan kehidupan sosial masyarakat.

Merujuk terhadap konsepsi pemidanaan itu cenderung dimulai dari konsepsi yang bersifat menghukum yang berorientasi ke belakang. Sistem pemenjaraan yang sangat menekankan pada unsur balas dendam dan penjeraan

1 Dwidja Priyatno, Sistem Pelaksanaan Pidana Penjara di Indonesia, Bandung: PT. Refika Aditama, 2006, Hlm. 2. yang disertai dengan lembaga "rumah penjara" secara berangsur-angsur dipandang sebagai suatu sistem dan sarana yang tidak sejalan dengan konsep rehabilitasi dan reintegrasi sosial, agar narapidana menyadari kesalahannya, tidak lagi berkehendak untuk melakukan tindak pidana dan kembali menjadi warga masyarakat yang bertanggung jawab bagi diri, keluarga, dan lingkungannya.

Sistem pemasyarakatan merupakan satu rangkaian kesatuan penegakan hukum pidana, oleh karena itu pelaksanaannya tidak dapat dipisahkan dari pengembangan konsepsi umum mengenai pemidanaan. Sistem pemasyarakatan disamping bertujuan untuk mengembalikan warga binaan pemasyarakatan sebagai warga yang baik, juga bertujuan untuk melindungi masyarakat terhadap kemungkinan diulanginya tindak pidana oleh warga binaan pemasyarakatan, serta merupakan penerapan dan bagian yang tak terpisahkan dari nilai-nilai yang terkandung dalam Pancasila.

Meskipun demikian penerapan sanksi pemidanaan haruslah mengutamakan hakhak narapidana sebagai warga negara Indonesia yang hilang kemerdekaannya karena melakukan tindak pidana, haruslah dilakukan sesuai dengan hak asasi manusia. Sering dijumpai dalam Lembaga Pemasyarakatan bahwa hak-hak narapidana belum diberikan sesuai dengan hak mereka sebagai warga negara. Hal ini disebabkan oleh beberapa faktor, di antaranya kurang dipahaminya peraturan mengenai hak-hak narapidana yang tertuang dalam undang-undang oleh petugas Lembaga Pemasyarakatan atau bahkan oleh narapidana sendiri. Sebagai negara hukum hak-hak narapidana harus dilindungi oleh hukum dan penegak hukum khususnya para staf di Lembaga Pemasyarakatan, sehingga merupakan sesuatu yang perlu bagi negara hukum untuk menghargai hak-hak asasi narapidana sebagai warga masyarakat yang harus diayomi walaupun telah melanggar hukum. Di samping itu 
narapidana perlu diayomi dari perlakuan tidak adil, misalnya penyiksaan, tidak mendapatkan fasilitas yang wajar dan tidak adanya kesempatan untuk mendapatkan remisi. Pidana penjara dalam sejarahnya dikenal sebagai reaksi masyarakat sebagai adanya tindak pidana yang dilakukan oleh seorang.

Dalam Undang-undang Republik Indonesia Nomor 12 Tahun 1995 tentang Permasyarakatan menyebutkan bahwa salah satu hak-hak dari narapidana adalah mendapatkan pelayanan kesehatan dan makanan yang layak, pelayanan kesehatan dan makanan yang memenuhi syarat kesehatan atau makanan sehat adalah makanan higienis, bergizi dan berkecukupan. Makanan yang higienis adalah makanan yang tidak mengandung kuman penyakit atau zat yang dapat membahayakan kesehatan. Makanan yang bergizi adalah makanan yang cukup mengandung karbohidrat, lemak, protein, mineral, vitamin, dalam jumlah yang seimbang sesuai dengan kebutuhan. Makanan yang berkecukupan adalah makanan yang dapat memenuhi kebutuhan tubuh pada usia dan kondisi tertentu. Selain memenuhi persyaratan pokok tersebut, perlu diperhatikan juga cara memasak makanan, suhu makanan pada saat disajikan, dan bahan.

Sedangkan untuk pemenuhan pelayanan kesehatan ini tidak hanya menyangkut penciptaan lingkungan yang baik, perlakukan yang sama, tapi termasuk pula pembenahan pelayanan kesehatan secara manusiawi yang diarahkan pada tingkatan harkat dan martabat, sehingga diharapkan dapat mengembangkan suatu masyarakat yang berkepribadian, dan saling menghormati.

Dalam konsepnya bahwa sistem pemasyarakatan memperlakukan orang dalam melaksanakan program pembinaan harus dalam kondisi sehat. Di dalam Lembaga Pemasyarakatan tidak semuanya narapidana dalam kondisi sehat, bagi narapidana yang sakit harus mendapatkan pelayanaan kesehatan yang optimal maka dari itu menurut Undang-undang Republik Indonesia Nomor 36 Tahun 2009 tentang Kesehatan, kesehatan adalah keadaan sehat, baik secara fisik, mental, spritual maupun sosial yang memungkinkan setiap orang untuk hidup produktif secara sosial dan ekonomis, diberikan hak pelayanaan kesehatan demikian pula bagi narapidana yang sedang menjalani masa pidananya di Lembaga Pemasyarakatan.

Pelayanan kesehatan yang diberikan di Lembaga Pemasyarakatan merupakan salah satu pemberian hak asasi manusia dari negara kepada warganya. Pelayanan kesehatan merupakan upaya preventif, dan rehabilitatif di bidang kesehatan bagi narapidana di Lembaga Pemasyarakatan, untuk terwujudnya pelayanan kesehatan yang baik bagi narapidana tidak terlepas dari tersedianya sarana dan prasarana kesehatan. $^{2}$

Maraknya kasus kriminalitas menyebabkan banyak pelaku tindak kejahatan yang harus menjalani masa hukumannya di Lembaga Pemasyarakatan. Data di Tahun 2017 menunjukkan jumlah warga binaan Lembaga Pemasyarakatan di seluruh Indonesia mencapai 168.894 orang. ${ }^{3}$ Hal ini berarti bahwa Lembaga Pemasyarakatan memiliki tugas dan fungsi yang sangat berat mengingat banyaknya jumlah warga binaan yang perlu mendapatkan perhatian selama menjalani masa hukuman di Lembaga Pemasyarakatan.

Selama menjalani masa hukumannya, narapidana memiliki hak-hak sebagaimana diatur dalam Pasal 14 Undang-undang Republik Indonesia Nomor 12 Tahun 1995 tentang Pemasyarakatan, yaitu:

a. Melakukan ibadah sesuai dengan agama atau kepercayaannya;

\footnotetext{
2"Pelaksanaan Pelayanan Kesehatan", http://adtyadjavanet.blogspot.com/2013/11/pe laksanaan-pelayanan-kesehatan.html., Diakses pada tanggal 30 Desember 2018.

3 "Menkumham Resmikan 13 Lapas Baru", http://www.hukumonline.com/berita/baca/lt55 3dc2454e2f9/menkumham-resmikan-13-lapasbaru. Diakses pada tanggal 30 Desember 2018.
} 
b. Mendapat perawatan, baik perawatan rohani maupun jasmani;

c. Mendapatkan pendidikan dan pengajaran;

d. Mendapatkan pelayanan kesehatan dan makanan yang layak;

e. Menyampaikan keluhan;

f. Mendapatkan bahan bacaan dan mengikuti siaran media massa lainnya yang tidak dilarang;

g. Mendapatkan upah atau premi atas pekerjaan yang dilakukan;

h. Menerima kunjungan keluarga, penasihat hukum, atau orang tertentu lainnya;

i. Mendapatkan pengurangan masa pidana (remisi);

j. Mendapatkan kesempatan berasimilasi termasuk cuti mengunjungi keluarga;

k. Mendapatkan pembebasan bersyarat;

l. Mendapatkan cuti menjelang bebas; dan

m. Mendapatkan hak-hak lain sesuai dengan peraturan perundangundangan yang berlaku.

Berdasarkan hak-hak yang tercantum dalam Undang-undang Pemasyarakatan, dapat terlihat bahwa makanan yang layak menjadi salah satu hak warga binaan yang harus menjadi perhatian karena setiap manusia memerlukan makanan yang layak dengan asupan gizi yang cukup agar dapat menjalani berbagai aktivitas sehari-hari. Hal ini sesuai yang tercantum dalam Pasal 25 ayat (1) Deklarasi Universal Hak-hak Asasi Manusia yang diterima dan diumumkan oleh Majelis Umum PBB pada tanggal 10 Desember 1948, menyatakan, "Setiap orang berhak atas tingkat hidup yang memadai untuk kesehatan dan kesejahteraan dirinya dan keluarganya, termasuk hak atas pangan, pakaian, perumahan dan perawatan kesehatan serta pelayanan sosial yang diperlukan, dan berhak atas jaminan pada saat menganggur, menderita sakit, cacat, menjadi janda/duda, mencapai usia lanjut atau keadaan lainnya yang mengakibatkannya kekurangan nafkah, yang berada di luar kekuasaannya."
Berkenaan dengan hal tersebut, dalam Pasal 19 ayat (1) Peraturan Pemerintah Republik Indonesia Nomor 99 Tahun 2012 tentang Perubahan Kedua Atas Peraturan Pemerintah Nomor 32 Tahun 1999 tentang Syarat dan Tata Cara Pelaksanaan Hak Warga Binaan Pemasyarakatan dikemukakan "Setiap narapidana dan anak didik pemasyarakatan berhak mendapatkan makanan dan minuman sesuai dengan jumlah kalori yang memenuhi syarat kesehatan." Dengan adanya Peraturan Pemerintah tersebut semakin memperkuat secara normatif akan hak-hak warga binaan pemasyarakatan, terutama yang terkait dengan pemberian makanan yang layak.

Pada kenyataannya, kondisi riil di Lembaga Pemasyarakatan menurut beberapa sumber, makanan yang diterima narapidana di Lembaga Pemasyarakatan masih dianggap kurang layak. Salah satu penyebabnya adalah adanya overkapasitas di Lembaga Pemasyarakatan yang mengakibatkan narapidana tidak mendapatkan asupan gizi yang memadai.

Fenomena ini terjadi di beberapa Lembaga Pemasyarakatan, seperti salah satunya di Lembaga Pemasyarakatan Pondok Rajeg Kabupaten Bogor yang narapidananya makin kurus sejak dijebloskan ke dalam sel. Pola makan yang tak teratur dan makanan yang kurang bergizi diduga menjadi penyebabnya, selain jumlah penghuni Lembaga Pemasyarakatan yang telah melebihi kapasitas, sehingga ruang gerak menjadi terbatas. $^{4}$ Penyebab lainnya menurut sumber di Ditjen Pemasyarakatan adalah karena tidak ada cita rasa pada makanan yang disediakan dan porsi makanan yang dianggap kurang memenuhi kebutuhan tubuh narapidana/tahanan sebagai akibat minimnya biaya makanan bagi narapidana/tahanan di Lembaga Pemasyarakatan sehingga kurang layak

\footnotetext{
4 "Napi Lapas Pondok Rajeg Kurus", http://aceh.tribunnews.com/2013/02/14/napilapas-pondokrajeg-kurus. Diakses pada tanggal 30 Desember 2018.
} 
untuk memenuhi kebutuhan narapidana selama di Lembaga Pemasyarakatan.

Hal ini dapat terlihat dari anggaran biaya makanan bagi narapidana/tahanan di Lembaga Pemasyarakatan yang hanya sebesar Rp. 14.000,- perorang/hari untuk Wilayah Indonesia Barat, Rp. 15.000,perorang/hari untuk Wilayah Indonesia Tengah, dan Rp. 17.000,- perorang/hari untuk Wilayah Indonesia Timur. ${ }^{5}$

Dalam hal ini Lembaga Pemasyarakatan memiliki biaya makanan bagi narapidana/tahanan yang terkecil bila dibandingkan dengan instansi lain, seperti kepolisian menganggarkan biaya makanan sebesar Rp. 30.000,- dan KPK yang menganggarkan biaya makanan sebesar Rp. 40.000,-. 6

Minimnya biaya makanan di Lembaga Pemasyarakatan menyebabkan narapidana/tahanan kekurangan sumber zat gizi yang dibutukan oleh tubuh untuk tumbuh dan memelihara kesehatan. Kualitas makanan dipengaruhi banyak faktor, seperti proporsi komponen mayor (lemak, protein dan karbohidrat) dan kandungan komponen minor yang meliputi vitamin dan mineral. ${ }^{7}$

Fenomena tersebut sangat memprihatinkan mengingat Deklarasi Universal tentang Pemberantasan Kelaparan dan Kekurangan Gizi yang diadopsi pada 16 November 1974 oleh Konferensi Pangan Dunia menyatakan bahwa setiap pria, wanita dan anak memiliki hak mutlak untuk bebas dari kelaparan dan kekurangan gizi dalam rangka untuk mengembangkan sepenuhnya dan mempertahankan kemampuan fisik dan mental mereka.

Berdasarkan isi dari instrumen internasional tersebut, dapat diketahui bahwa warga binaan pemasyarakatan

\footnotetext{
${ }^{5}$ Ibid.

6 "Biaya Makan Tahanan di KPK Paling Mahal", https://m.tempo.co/read/news/2014/03/12/0 63561591/biaya-makan-tahanan-di-kpk-palingmahal. Diakses pada tanggal 30 Desember 2018.

7 Jansen Selalahi, Makanan Fungsional, Yogyakarta: Kanisius, 2006, Hlm. 32.
}

memiliki hak untuk bebas atas rasa lapar dan kekurangan gizi, sehingga hak atas makanan dan minuman yang layak pun harus terpenuhi. Pada kenyataannya walaupun tugas dan fungsi Lembaga Pemasyarakatan sebagai lembaga yang melakukan layanan, pembinaan dan perawatan bagi warga binaan, namun hal tersebut tidak akan berjalan optimal tanpa adanya dukungan dana untuk memenuhi kebutuhan makanan yang layak bagi warga binaan. Padahal pemberian makanan yang layak telah diatur pula dalam Peraturan Menteri Hukum dan Hak Asasi Manusia Republik Indonesia Nomor: M.HH01.PK.07.02 Tahun 2009 tentang Pedoman Penyelenggaraan Makanan Bagi Warga Binaan Pemasyarakatan di Lembaga Pemasyarakatan dan Rumah Tahanan Negara.

Kurang terpenuhinya hak warga binaan pemasyarakatan akan perawatan dalam bentuk penyediaan makanan yang layak akan berdampak adanya ketidakpuasan warga binaan akan kebutuhan dasarnya, sehingga mereka pun mencari alternatif lain untuk memenuhi kebutuhannya tersebut. Dalam upaya pemenuhan kebutuhan, warga binaan dapat melakukan hal-hal negatif yang berdampak pada tindakan kriminal di dalam Lembaga Pemasyarakatan. Oleh karena itu perlu adanya perhatian pemerintah akan hal tersebut sebagaimana tercantum dalam Pasal 28 I Undangundang Dasar Negara RI Tahun 1945 yang menyatakan bahwa perlindungan, pemajuan, penegakan, dan pemenuhan hak asasi manusia adalah tanggung jawab negara, terutama pemerintah.

Berdasarkan uraian latar belakang masalah tersebut di atas, maka peneliti dalam penelitian ini mengambil judul tentang: "ASAS KEADILAN DALAM SUPLAI MAKAN TAHANAN KEPOLISIAN DAN LEMBAGA PEMASYARAKATAN DIHUBUNGKAN DENGAN UNDANGUNDANG NOMOR 36 TAHUN 2009". 
Berdasarkan latar belakang masalah yang telah diuraikan di atas, peneliti mengidentifikasi masalah sebagai berikut:

1. Bagaimana mekanisme pengadaan suplai makan tahanan Kepolisian dan Lembaga Pemasyarakatan?

2. Bagaimana pengadaan barang dan jasa di bidang makan tahanan Kepolisian dan Lembaga Pemasyarakatan untuk tercapainya keadilan?

\section{METODE PENELITIAN}

Metode penelitian yang digunakan dalam penelitian ini adalah pendekatan yuridis normatif, yaitu hukum dikonsepsikan sebagai norma, kaidah, asas atau dogma-dogma/yurisprudensi dan pendekatan yuridis empiris yaitu hukum sebagai gejala masyarakat, sebagai institusi sosial atau perilaku yang mempola.

\section{PEMBAHASAN}

\section{A. MEKANISME PENGADAAN SUPLAI MAKAN TAHANAN KEPOLISIAN DAN LEMBAGA PEMASYARAKATAN}

Seseorang yang diputuskan harus menjalani pidana penjara di Lembaga Pemasyarakatan mengalami suatu pidana berupa pembatasan kebebasan bergerak dari seorang terpidana, yang dilakukan dengan mengisolasi orang tersebut di dalam sebuah Lembaga Pemasyarakatan. Pihak Lapas mewajibkan orang tersebut untuk menaati semua peraturan tata tertib yang berlaku dalam Lembaga Pemasyarakatan, yang dikaitkan dengan suatu tindakan tata tertib yang berlaku dalam Lembaga Pemasyarakatan, yang dikaitkan dengan suatu tindakan tata tertib bagi mereka yang telah melanggar peraturan tersebut. 8

Hak terkait makanan yang layak merupakan hak yang dimiliki oleh setiap manusia, termasuk narapidana. Hal ini dikarenakan hak tersebut termasuk dalam

8 Yesmil Anwar dan Adang, Pembaruan Hukum Pidana, Reformasi Hukum Pidana, Jakarta: Grasindo, 2008, Hlm. 130. salah satu hak asasi manusia. Dalam hal ini Miriam Budiardjo mengemukakan bahwa "Hak asasi manusia adalah hak yang dimiliki manusia yang telah diperoleh dan dibawanya bersamaan dengan kelahirannya di dalam kehidupan masyarakat. Dianggap bahwa beberapa hak itu dimilikinya tanpa perbedaan atas dasar bangsa, ras, agama, kelamin dan karena itu bersifat universal. Dasar dari semua hak asasi ialah bahwa manusia memperoleh kesempatan berkembang sesuai dengan harkat dan cita-citanya. ${ }^{9}$

$$
\text { Narapidana bukan saja obyek }
$$
melainkan juga subyek yang dapat melakukan kesalahan atau kekhilafan yang dapat dikenakan pidana, sehingga tidak harus diberantas. Oleh karenanya yang harus diberantas adalah faktor-faktor yang dapat menyebabkan narapidana berbuat hal-hal ysng bertentangan dengan hukum, kesusilaan, agama, atau kewajibankewajiban sosial lain yang dapat dikenakan pidana. Pemidanaan adalah upaya untuk menyadarkan narapidana atau anak pidana agar menyesali perbuatannya, mengembalikannya menjadi warga masyarakat yang baik, taat kepada hukum, menjunjung tinggi nilai-nilai moral, sosial dan keagamaan, sehingga tercapai kehidupan masyarakat yang aman, tertib dan damai. ${ }^{10}$

Berkenaan dengan hak-hak yang dimilikinya, narapidana adalah manusia yang memiliki kebutuhan dasar yang harus dipenuhi dalam rangka mempertahankan kehidupannya. Dalam hal ini pemerintah harus memenuhi kebutuhan dasar dari narapidana yang menjalani hukuman berdasarkan penetapan putusan pengadilan. Pengaturan mengenai penyelenggaraan makan narapidana tercantum dalam Peraturan Menteri Hukum dan Hak Asasi Manusia Nomor

\footnotetext{
${ }^{9}$ Miriam Budiarjo, Dasar-dasar Ilmu Politik, Jakarta: Penerbit PT Gramedia, 1980, Hlm. 120.

10 Anggun Malinda, Perempuan dalam Sisten Peradilan Pidana (Tersangka, Terdakwa, Terpidana, Saksi, Korban), Yogyakarta: Garudhawaca, 2016, Hlm. 26.
} 
M.HH-01.PK.07.02 Tahun 2009 tentang Pedoman Penyelenggaraan Makanan Bagi Warga Binaan Pemasyarakatan di Lembaga Pemasyarakatan dan Rumah Tahanan Negara.

Dengan peraturan tersebut, maka penyelenggaraan makanan di Lapas dan Rutan dilaksanakan dimulai dari proses perencanaan anggaran, perencanaan menu, perhitungan kebutuhan bahan makanan, pemesanan dan pembelian bahan makanan, penerimaan, penyimpanan, persiapan, pengolahan bahan makanan, pendistribusian makanan, monitoring, evaluasi, pencatatan dan pelaporan.

Perencanaan anggaran dimulai dari usulan Lapas/Rutan melalui Kantor Wilayah Kementerian Hukum dan HAM, diajukan ke Sekretariat Jenderal Kementerian Hukum dan HAM dan diputuskan oleh Sekretariat Jenderal Kementerian Hukum dan HAM. Dalam hal ini anggaran untuk penyediaan makan narapidana belum mengalami perubahan sampai saat ini dengan jumlah anggaran yang disesuaikan dengan wilayah rayon yaitu rayon 1 untuk Indonesia Barat memiliki pagu biaya makanan narapidana dan tahanan sebesar $\mathrm{Rp}, 14.000,-.$, rayon 2 untuk Indonesia Tengah dengan pagu biaya makanan sebesar Rp. 15.000,- dan rayon 3 untuk Indonesia Timur dengan pagu biaya makanan sebesar Rp. 17.000,-.

Hal ini sangat memprihatinkan mengingat narapidana membutuhkan makanan sebagai sumber energi bagi dirinya dalam melakukan aktivitas selama menjalani masa hukumannya. Oleh karena itu dengan anggaran yang ada, maka diperlukan perencanaan menu bagi narapidana agar mereka mendapatkan makanan dengan asupan gizi yang memadai.

Perencanaan menu perlu dilakukan dalam penyediaan makanan dan minuman yang layak di Lapas yang bertujuan agar tersedianya siklus menu sesuai klasifikasi pelayanan yang ada di Lapas/Rutan dalam kurun waktu tertentu. Pada penyusunan menu dipertimbangkan faktor yang mempengaruhi antara lain standar porsi dan peraturan pemberian makanan. Penyusunan menu dilakukan oleh Direktorat Jenderal Pemasyarakatan Kementerian Hukum dan HAM dengan memperhatikan kebiasaan makan dan ketersediaan bahan makanan di daerah.

Selain itu juga perencanaan menu dilakukan dengan memperhatikan standar kecukupan gizi bagi narapidana, yang dikeluarkan Kementerian Kesehatan RI. Dengan angka kecukupan gizi bagi narapidana/tahanan, Ditjen Pemasyarakatan berupaya memberikan contoh menu 10 hari narapidana/tahanan yang ditempelkan di setiap Lapas di Indonesia. Dengan adanya contoh menu 10 hari bagi narapidana/tahanan, diharapkan Lapas dapat menyediakan makanan yang layak bagi narapidana sesuai angka kecukupan gizi dan cita rasa daerah tiaptiap provinsi.

Pada kenyataannya, implementasi dari pemberian contoh menu 10 hari bagi narapidana/tahanan tersebut tidak sesuai dengan yang diharapkan. Hal ini dikarenakan adanya salah persepsi dan interprestasi mengenai pengertian yang ada di pedoman, sehingga mereka memberikan makan sesuai dengan dasar contoh menu yang ditempel tersebut. Oleh karena itu di berbagai provinsi, terlihat Lapas menggunakan menu yang sama.

Menurut informan dari Direktorat Jenderal Pemasyarakatan, Lapas seharusnya memiliki kreativitas dan inovasi, sehingga menu disesuaikan dengan cita rasa mulut mereka. Sebagai contoh di Kalimantan yang menyukai rotan direbus dan digulai, maka pihak Lapas dapat membuat makanan tersebut sesuai cita rasa yang dimiliki daerah tersebut dengan tidak mengurangi esensi AKG atau angka kecukupan gizi. Misalnya, Dalam membahas Angka Kecukupan Gizi, maka 345 kilo kalori sama dengan menyajikan nasi, sayur rotan muda dan ikan siluang. Menu tersebut sama nilainya dengan sayur asem dengan ayam. Hal tersebut berarti di konversi dengan tidak mengurangi $\mathrm{AKG}$, 
hanya beda cita rasa. Pada kenyataannya, belum sama mindsetnya, sehingga di Jawa dan Papua memiliki menu makanan yang sama. Dalam hal ini seharusnya di Yogyakarta memasak gudeg, maka di Papua makan singkong karena orang Papua tidak merasa kenyang sebelum makan singkong. Oleh karena itu harus diimbangi, yang seharusnyanya nasi 400 kilo kalori, dapat dikurangin menjadi 200 kilo kalori beras dan 200 untuk singkong.

Dengan tercukupinya angka kecukupan gizi para narapidana seharusnya tidak ada pemberitaan di media massa mengenai narapidana yang kekurangan gizi di Lembaga Pemasyarakatan. Setelah dikonfirmasi dengan informan dari Ditjen Pemasyarakatan mengenai pemberitaan tersebut, yang bersangkutan tidak menyangkal bahwa ada lapas yang narapidananya kekurangan gizi. Hal ini bisa saja terjadi karena adanya sistem lelang pada bahan makanan. Dalam sistem lelang tersebut, penawaran dengan harga terendah adalah yang akan dimenangkan, sehingga pagu biaya makanan yang semula Rp. 14.000,- sehari untuk satu orang menjadi Rp. 10.000,-. Dengan harga tersebut, maka akan berdampak pada mutu makanan, sehingga kebutuhan makan narapidana pun tidak sesuai dengan angka kecukupan gizi yang telah ditentukan.

Berdasarkan hal tersebut, maka dapat diketahui bahwa adanya Lapas yang narapidana/tahanan kekurangan gizi bukan disebabkan karena adanya over kapasitas seperti informasi yang dikemukakan oleh media massa. Hal ini juga diungkapkan oleh informan dari Ditjen Pemasyarakatan, yang mengemukakan bahwa bukan overkapasitas yang menyebabkan makanan tidak layak. Tetapi makanan tersebut dianggap tidak layak oleh narapidana/tahanan sehingga tidak dimakan, dengan alasan tidak ada cita rasa dan porsi yang kurang memadai.

Penyediaan makanan yang layak juga terkait dengan pengolahannya yaitu memasak. Pada Peraturan Menteri Hukum dan Hak Asasi Manusia Nomor M.HH-01.
PK.07.02 Tahun 2009 tentang Pedoman Penyelenggaraan Makanan Bagi Warga Binaan Pemasyarakatan di Lembaga Pemasyarakatan dan Rumah Tahanan Negara sudah ditentukan mengenai tenaga yang diperlukan untuk penyelenggaran makanan yaitu:

1. Petugas dapur idealnya berlatar belakang pendidikan tata boga atau berpengalaman dibidang tersebut;

2. Petugas dapur bertanggung jawab terhadap pengolahan bahan makanan mulai dari persiapan bahan makanan sampai dengan pendistribusian;

3. Pemuka dan tamping bertugas membantu proses pelaksanaan penyelenggaraan makanan;

4. Idealnya pengelolaan penyelenggaraan makanan di Lapas/Rutan melibatkan ahli gizi (D3 Gizi) yang bertugas sebagai supervisor, mengawasi dan mengendalikan penyelenggaraan makanan di Lapas/Rutan, mulai dari perencanaan sampai dengan pendistribusian makanan.

5. Rasio juru masak dengan WBP dan tahanan adalah 1: $75 \quad-100$ orang. Minimal juru masak berjumlah 5 ( lima ) orang.

6. Dalam pelaksanaan tugasnya juru masak melakukan kegiatan:

a. Mempersiapkan/meracik bahan makanan.

b. Memasak/mengolah makanan.

c. Mendistribusikan.

d. Memperhatikan kebersihan sarana dan prasarana.

Pada kenyataanya belum semua tenaga yang diperlukan dalam penyelenggaraan makanan terpenuhi di Lapas. Menurut informan, sampai saat ini Lapas belum ada ahli gizi, karena tidak memungkinkan untuk pengadaan tenaga profesional, sehingga masih menggunakan tenaga orang dalam seperti pegawai sebagai koordinator dapur dengan harapan mereka bisa mengetahui tentang gizi walau sedikit. Dalam aturan juga dikemukakan bahwa juru masak harus yang ahli memasak, selain itu ada asisten juru masak yang 
memiliki tugas memotong bahan makanan, mencuci piring dan sebagainya. Semua itu belum terpenuhi. Sehingga narapidan yang melakukannya. Akan tetapi dalam pedoman penyelenggaraan makanan memperbolehkan untuk dibantu narapidana sepanjang tidak ada tenaga tersebut.

Sarana dan prasarana menjadi faktor penting lainnya yang perlu diperhatikan dalam perawatan fisik terkait makanan bagi narapidana. Menurut informan, sarana dan prasarana yang ada yang belum sesuai standar. Salah satu contohnya adalah dalam memasak nasi di Lapas, masih ada yang diliwet, ada yang memakai dandang wajan dan ada yang sudah pakai steamer. Dalam memasak nasi seharusnya semuanya terstandar, dan sudah menggunakan steamer untuk memasak nasi. Begitupun dengan panci untuk sayur ukurannya harus sesuai dengan porsi yang akan dimasak.

Banyaknya hal yang belum terpenuhi dalam upaya penyelenggaraan makanan dan minuman di Lapas menyebabkan Ditjen Pemasyarakatan berupaya melakukan perbaikan di bidang perawatan fisik terkait makanan dengan membuat standar penyelenggaraan makanan berdasarkan Keputusan Direktur Jenderal Pemasyarakatan Kementerian Hukum dan Hak Asasi Manusia Republik Indonesia, Nomor PAS - 498.PK.01.07.02 TAHUN 2015 tentang Standar Penyelenggaraan Makanan di Lembaga Pemasyarakatan, Rumah Tahanan Negara dan Cabang Rumah Tahanan Negara. Akan tetapi pelaksanaan standar penyelenggaaraan makanan tersebut dilakukan secara bertahap mengingat anggaran yang ada masih terbatas.

Setiap bahan pangan mempunyai susunan kimia yang berbeda dan mengandung zat gizi yang bervariasi baik jenis dan jumlahnya. ${ }^{11}$ Hak atas pangan merupakan salah satu hak yang dimiliki manusia sebagaimana tertuang dalam Pasal

11 Tiurma PT Simanjuntak, Tiurma, Komponen Gizi dan Terapi Pangan Ala Papua, Yogyakarta: Deepublish, 2014, Hlm. 1
25 ayat (1) Deklarasi Universal Hak-hak Asasi Manusia. Untuk kelangsungan hidupnya, setiap manusia membutukan makanan agar mereka mendapatkan enegi untuk melakukan aktivitas. Dalam hal ini makanan merupakan hak yang tidak dapat dilanggar atau dikurangi karena tergolong sebagai non-derogble right. Begitupun dengan narapidana yang perlu pemenuhan dalam non-derogable right yang berupa penyediaan makanan yang layak di Lembaga Pemasyarakatan.

Lembaga Pemasyarakatan sebagai tempat pembinaan narapidana, agar keberadaannya dapat diterima kembali oleh masyarakat sewaktu bebas memiliki berbagai program atau kegiatan yang salah satunya adalah perawatan fisik narapidana terkait makanan. Kenyataan bahwa sebagian besar Lapas menyediakan menu yang sama sesuai contoh menu yang disampaikan perlu menjadi bahan pertimbangan Ditjen Pemasyarakatan untuk meminta pihak Lapas untuk tidak meminta bahan makanan yang diperlukan saja, melainkan menu siklus 10 hari yang akan dimasak oleh tiap Lapas. Hal ini dikarenakan sebagian besar Lapas mengajukan permintaan bahan makanan yang sama dengan makanan ringan yang sama pula yaitu ubi jalar.

Permintaan bahan makanan dapat terlihat bahwa minimnya anggaran yang ada menyebabkan Lapas mempertimbangkan untuk menggunakan bahan makanan yang sama setiap bulannya agar dapat mencukupi kebutuhan makan narapidana.

Walaupun demikian, perumusan kebijakan manajeman perawatan fisik yang terkait makanan di Lapas pada dasarnya sudah sesuai dengan Teori Hirarki Kebutuhan Maslow, khususnya Physiological Needs (kebutuhan fisiologis). Pemerintah telah berupaya mengintegrasikan norma dan prinsip hak asasi manusia. Hal ini dikarenakan peraturan yang berkaitan dengan hal tersebut sudah disesuaikan dengan Pasal 20 ayat (1) dan ayat (2) Peraturan Standar 
Minimum Perlakuan terhadap Tahanan yang diadopsi oleh Kongres I PBB tentang Pencegahan Kejahatan dan Pengobatan Pelanggar, diadakan di Jenewa pada Tahun 1955, dan disetujui oleh Ekonomi dan Sosial Dewan oleh resolusinya 663 C (XXIV) tanggal 31 Juli 1957 dan 2076 (LXII) pada 13 Mei 1977, yang menyatakan:

(1) Setiap tahanan harus disediakan oleh pemerintah pada jam-jam biasa dengan makanan nilai gizi yang memadai untuk kesehatan dan kekuatan, kualitas sehat dan dipersiapkan dengan baik dan disajikan.

(2) Air minum harus tersedia bagi setiap narapidana kapan pun dia membutuhkannya.

Hal ini dapat terlihat dari pemberian makan narapidana sebanyak 3 (tiga) kali sehari yaitu pada saat pagi, siang dan jam lima sebelum masuk sel. Begitupun dengan Standar Penyelenggaraan Makanan di Lembaga Pemasyarakatan, Rumah Tahanan Negara dan Cabang Rumah Tahanan Negara telah mengemukakan secara rinci mengenai berbagai hal yang perlu dilakukan agar narapidana memperoleh makanan yang layak sesuai dengan standar yang telah ditetapkan tersebut, termasuk contoh menu siklus 10 hari bagi narapidana yang dipisahkan menurut wilayah Indonesia Barat, Wilayah Indonesia Tengah dan Wilayah Indonesia Timur.

Untuk mewujudkan terlaksananya pemisahan terhadap menu siklus 10 hari per wilayah tersebut, Direktorat Jenderal Pemasyarakatan berupaya untuk melakukan sosialisasi ke Kanwil Kementerian Hukum dan HAM di seluruh Indonesia berkaitan dengan standar penyelenggaraan makan yang ditelh disusun, termasuk contoh menu siklus 10 hari pada setiap Wilayah Indonesia tersebut.

Akan tetapi standar penyelenggaraan makanan tersebut tidak dapat terimplementasi dengan baik bila standar pemberian makanan bagi narapidana masih mengacu pada Surat Edaran Menteri Kehakiman RI No.M.02. UM.01.06 Tahun 1989 tentang petunjuk pelaksanaan biaya bama bagi napi/tahanan negara/anak, sehingga menyebabkan biaya makanan narapidana/tahanan perharinya masih sekitar Rp. 14.000,-.

Surat Edaran Menteri Kehakiman RI No.M.02.UM.01.06 Tahun 1989 tentang Petunjuk Pelaksanaan Biaya Bama Bagi Napi/Tahanan Negara /Anak sudah tidak dapat digunakan lagi mengingat dalam surat edaran tersebut di antaranya menyebutkan bahwa satuan harga pengadaan non beras (lau-pauk) termasuk bahan makan dan pengangkatannya ditetapkan sebesar Rp. 600,- per hari. Selain itu satuan harga makanan extra (extra voeding) bagi napi/tahanan negara/anak ditetapkan sebesar Rp. 100,seorang per hari.

Dalam Surat Edaran Menteri Kehakiman RI No.M.02.UM.01.06 Tahun 1989 juga dikemukakan mengenai daftar menu yang menyebutkan bahwa pemberian makanan kepada napi/tahanan negara/anak berkisar 2.250 kalori per orang per hari.

Dari isi Surat Edaran Menteri Kehakiman RI No.M.02.UM.01.06 Tahun 1989, dapat terlihat bahwa satuan harga biaya bahan makanan yang tercantum dalam surat edaran tersebut sudah tidak relevan dengan harga bahan makanan saat ini mengingat Indonsia telah mengalami beberapa kali inflasi yang menyebabkan kenaikan harga bahan makanan.

Berdasarkan hal tersebut, biaya makanan bagi narapidana/tahanan pun hanya mencapai angka Rp. 14.000,- untuk Wilayah Indonesia Bagian Barat, Rp. 16.000,- untuk wilayah Indonesia Bagian Tengah dan Rp. 17.000,- untuk Wilayah Indonesia Bagian Timur. Jumlah biaya makanan tersebut untuk 3 (tiga) kali makan bagi narapidana menjadi perhatian banyak pihak, sehingga di berbagai pemberitaan media massa pun banyak yang memberitakan mengenai Lapas di 
daerah-daerah yang narapidananya kurang gizi karena anggaran yang ada tidak sebanding dengan jumlah narapidana yang overkapasitas. Hal ini sangat memprihatinkan mengingat pada Peraturan Menteri Hukum dan Hak Asasi Manusia Nomor M.HH-01.PK.07.02 Tahun 2009 tentang Pedoman Penyelenggaraan Makanan Bagi Warga Binaan Pemasyarakatan di Lembaga Pemasyarakatan dan Rumah Tahanan Negara telah dikemukakan mengenai perhitungan kebutuhan bahan makanan untuk pengadaan bahan makanan sesuai menu yang ditetapkan dan jumlah Warga Binaan Pemasyarakatan dan Tahanan, dengan tujuan untuk tercapainya usulan dan kebutuhan bahan makanan untuk WBP dan tahanan selama satu tahun.

Selain itu pengadaan bahan makanan dengan sistem lelang yang memenangkan penawaran dengan harga terendah menjadi salah satu penyebab tidak adanya kenaikan biaya makanan bagi narapidana dan tahanan di Lapas. Dalam hal ini Ditjen Pemasyarakatan dan Lapas telah berupaya mengikuti aturan yang terdapat dalam Pasal 36 ayat (1) Peraturan Presiden RI Nomor 54 Tahun 2010 tentang Pengadaan Barang dan Jasa yang mengemukakan bahwa Pemilihan Penyedia Barang/Pekerjaan Konstruksi/Jasa Lainnya pada prinsipnya dilakukan melalui metode Pelelangan Umum dengan pascakualifikasi.

Walaupun Ditjen Pemasyarakatan telah mengeluarkan Surat Edaran Nomor: PAS295.PK.01.07.02 Tahun 2016 tentang Penentuan Pemenang Pengadaan Bahan Makanan di Lembaga Pemasyarakatan/Lembaga Pembinaan Khusus Anak/Rumah Tahanan Negara/Cabang Rumah Tahanan Negara, tetapi pelaksanaannya tetap saja harus mengacu pada peraturan pengadaan barang dan jasa yang ada, sehingga biaya makanan bagi narapidana dan tahanan tidak mengalami kenaikan.

Dalam hal ini contoh pelaksanaan dari Surat Edaran yang telah dikeluarkan yaitu bila ada penawaran harga Rp. 13.000,- untuk biaya bahan makanan, maka penawaran tersebut akan diambil dibanding dengan penawaran harga Rp. 10.000,- Dalam hal ini panitia pengadaan barang dan jasa telah memenuhi syarat Peraturan Presiden Nomor 54 Tahun 2010 yaitu dengan mengambil harga di bawah pagu anggaran yang semula seharga Rp. 14.000,- menjadi 13.000,- dengan masih mempertimbangkan rasionalitas kewajaran untuk harga bahan makanan.

Dengan demikian, Peraturan Menteri Hukum dan Hak Asasi Manusia Nomor M.HH-01.PK.07.02 Tahun 2009 tentang Pedoman Penyelenggaraan Makanan Bagi Warga Binaan Pemasyarakatan di Lembaga Pemasyarakatan dan Rumah Tahanan Negara sudah tidak relevan lagi dilaksanakan mengingat masih menggunakan Surat Edaran Menteri Kehakiman RI No.M.02.UM.01.06 Tahun 1989 tentang Petunjuk Pelaksanaan Biaya Bama Bagi Napi/Tahanan Negara/Anak sebagai acuannya. Oleh karena itu perlu melakukan revisi atas pedoman penyelenggaraan makanan tersebut terutama berkaitan dengan petunjuk pelaksanaan biaya bama bagi napi/tahanan negara /anak agar mengacu pada aturan yang baru, sehingga biaya bahan makanan di Lapas mengalami peningkatan dan pelaksanaannya sesuai dengan standar penyelenggaraan makanan yang ditetapkan oleh Direktur Jenderal Pemasyarakatan.

\section{B. PENGADAAN BARANG DAN JASA DI BIDANG MAKAN TAHANAN KEPOLISIAN DAN LEMBAGA PEMASYARAKATAN UNTUK TERCAPAINYA KEADILAN}

Penyelenggaraan makanan bagi narapidana dan tahanan merupakan salah satu kegiatan untuk memenuhi kebutuhan gizi narapidana, sebagai wujud perlindungan hak narapidana dan tahanan. Adapun pelaksanaan pengadaan barang dan jasa makanan narapidana dan tahanan dilakukan dengan cara pelelangan yang diatur dalam Peraturan Presiden Nomor 54 
Tahun 2010 beserta perubahannya tentang Pengadaan Barang dan Jasa Pemerintah dan peraturan khusus mengenai pengadaan bahan makanan bagi narapidana, yakni Peraturan Menteri Hukum dan Hak Asasi Manusia Nomor M.HH172.PL.02.03 Tahun 2011 tentang Pedoman Pengadaan Bahan Makanan Bagi Narapidana, Tahanan, dan Anak Didik Pemasyarakatan Pada Lembaga Pemasyarakatan dan Rumah Tahanan Negara di Lingkungan Kementerian Hukum dan Hak Asasi Manusia.

Pada saat proses pelelangan banyak terjadi hambatan dan kendala-kendala yang dihadapi baik dalam proses pelelangan maupun pada saat memasukkan dokumen kedalam aplikasi. Penyedia bahan makanan narapidana dan tahanan dalam pelaksanaannya dilaksanakan selama 365 (tiga ratus enam puluh lima) hari atau selama 1 (satu) tahun, sehingga pada tahun berikutnya tepat pada tanggal 1 (satu) Januari harus ada penyedia barang/jasa lainnya untuk melaksanankan pengadaan bahan makanan tersebut, namun pada Lembaga Pemasyarakatan Kelas IIA Cibinong pada Tahun 2018 tidak memperoleh penyedia barang/jasa pada tanggal 1 (satu) Januari sehingga pengadaan barang/jasa bahan makanan narapidana dan tahanan dilaksanakan oleh Kuasa Pengguna Anggaran (KPA) Lembaga Pemasyarakatan Kelas IIA Cibinong.

Undang-undang No. 12 Tahun 1995 tentang Pemasyarakatan yang tercatum dalam Pasal 14 menyebutkan mengenai hak-hak yang harus dipenuhi termasuk di dalamnya hak memperoleh pelayanan makanan yang layak. ${ }^{12}$

KPA mempunyai wewenang untuk melakukan pelelangan bahan makanan narapidana dan tahanan diatur dalam Pasal 8 ayat (1) Peraturah Pemerintah Nomor 16 Tahun 2018 tentang Pengadaan Barang/Jasa Pemerintah. Pasal 1 Undangundang Nomor 12 tahun 1995 tentang Pemasyarakatan menyebutkan Kepala

\footnotetext{
12 Dwi Priyatno, Op.Cit., Hlm. 128
}

Lembaga Pemasyarakatan mempunyai wewenang untuk melaksanakan pembinaan terhadap narapidana dan tahanan di dalam Lembaga Pemasyarakatan. ${ }^{13}$

Proses dalam melakukan pelelangan harus sesuai dengan etika pelelangan atau pengadaan barang/jasa sebagaimana diatur dalam Pasal 6 Perpres Nomor 4 Tahun 2015 sebagai berikut:

a. Melaksanakan tugas secara tertib, disertai rasa tanggung jawab untuk mencapai sasaran, kelancaran dan ketepatan tercapainya tujuan pelelangan atau pengadaan barang/ jasa;

b. Bekerja secara profesional dan mandiri, serta menjaga kerahasiaan dokumen pengadaan barang/jasa yang menurut sifatnya harus dirahasiakan untuk mencegah terjadinya penyimpangan dalam pelelangan atau pengadaan barang/ jasa;

c. Tidak saling mempengaruhi baik langsung maupun tidak langsung yang berakibat terjadinya persaingan tidak sehat;

d. Menerima dan bertanggung jawab atas segala keputusan yang tetapkan sesuai dengan kesepakatan tertulis para pihak;

e. Menghindari dan mencegah terjadinya pertentangan kepentingan para pihak yang terkait, baik secara langsung maupun tidak langsung dalam proses pelelangan atau pengadaan barang/ jasa;

f. Menghindari dan mencegah terjadinya pemborosan dan kebocoran keuangan negara dalam pelelangan atau pengadaan barang/ jasa;

g. Menghindari dan mencegah penyalahgunaan wewenang dan/atau kolusi dengan tujuan untuk keuntungan pribadi, golongan atau pihak lain yang secara langsung atau tidak langsung merugikan negara;

13 Adrian Sutedi, Aspek Hukum Pengadaan Barang dan Jasa dan Berbagai Permasalahannya, Jakarta: Sinar Grafika, 2008, Hlm. 39. 
h. Tidak menerima, tidak menawarkan atau tidak menjanjikan untuk memberi atau menerima hadiah, imbalan, komisi, rabat dan berupa apa saja dari atau kepada siapapun yang diketahui atau patut diduga berkaitan dengan pelelangan atau pengadaan barang/jasa.

Prinsip yang harus dijadikan dasar dalam melaksanakan proses pelelangan atau pengadaan barang/jasa yaitu:

a. Efisien, pengadaan barang/jasa harus diusahakan dengan menggunakan dana dan daya yang terbatas untuk mencapai sasaran yang ditetapkan dalam waktu sesingkat-singkatnya dan dapat dipertanggungjawabkan.

b. Efektif, berarti pelelangan atau pengadaan barang/jasa harus sesuai dengan kebutuhan dan sasaran yang telah ditetapkan serta memberikan manfaat yang sebesarbesarnya.

c. Transparan, berarti semua ketentuan dan informasi mengenai pelelangan atau pengadaan barang/jasa termasuk syarat teknis administrasi pengadaan, tata cara evaluasi, hasil evaluasi, penetapan calon penyedia barang/jasa, sifatnya terbuka bagi peserta penyedia barang/jasa yang berminat serta bagi masyarakat luas dan umumnya.

d. Terbuka, berarti pengadaan barang/jasa dapat diikuti oleh penyedia barang/jasa yang memenuhi persyaratan/kriteria tertentu berdasarkan ketentuan dan prosedur yang jelas.

e. Bersaing, berarti pelelangan atau pengadaan barang/jasa harus dilakukan melalui persaingan yang sehat di antara sebanyak mungkin penyedia barang/jasa yang setara dan memenuhi persyaratan, sehingga dapat diperoleh barang/jasa yang ditawarkan secara kompetitif dan tidak ada intervensi yang menggangu terciptanya mekanisme pasar dalam pengadaan barang/jasa.

f. Adil/tidak diskriminatif, berarti memberikan perlakuan yang sama bagi calon penyedia barang/jasa yang tidak mengarah untuk memberi keuntungan kepada pihak tertentu, dengan tetap memperhatikan kepentingan nasional.

g. Akuntabel, berarti harus mencapai sasaran baik fisik, keuangan maupun manfaat bagi kelancaran pelaksanaan tugas umum pemerintah dan pelayanan masyarakat sesuai prinsipprinsip serta ketentuan yang berlaku dalam pengadaan barang/jasa.

Tahapan pelaksanaan pelelangan bahan makanan narapidana dan tahanan yang diatur dalam Peraturan Presiden Nomor 16 Tahun 2018 tentang Pengadaan Barang dan Jasa Pemerintah Pasal 22 sampai dengan pasal 32. Sebelum memulai proses pelelangan wewenang KPA dimulai saat penyusunan anggaran sebagai berikut:

a. Perencanaan Anggaran;

b. Perencanaan Menu;

c. Perhitungan Kebutuhan Bahan Makanan;

d. Pengadaan Bahan Makanan;

e. Pemesanan, Penerimaan dan Penyimpanan Bahan Makanan;

f. Persiapan dan pengolahan bahan makanan;

g. Pendistribusian Makana;

h. Pencatatan dan Pelaporan.

Mekanisme pada saat proses pelelangan bahan makanan narapidana dan tahanan wewenang KPA adalah dimulai dari penyusunan kelompok kerja pelelangan, pembuatan harga perhitungan sendiri, sedangkan saat pengumuman dan dokumen sampai dengan pengumuman penyedia merupakan tanggung jawab kelompok kerja unit layanan pengadaan.

Pelelangan bahan makanan narapidana dan tahanan dilaksanakan pada saat Daftar Isian Pelaksanaan Anggaran (DIPA) Lembaga Pemasyarakatan definitif yaitu bulan Desember. Hal ini dilakukan untuk memperoleh penyedia bahan makanan pada tanggal 1 Januari tahun berikutnya sudah ada penandatangan kontrak untuk penyedia yang memasukkan makanan narapidana dan tahanan ke Lembaga Pemasyarakatan. 
Penyedia bahan makanan narapidana dan tahanan pelaksanaannya berlangsung selama 1 (satu) tahun terhitung dari tanggal 1 Januari sampai dengan 31 Desember. Demikian juga anggaran yang tersedia dalam DIPA disusun dalam 1 (satu) tahun, namun dalam pelaksanaannya jumlah narapidana dan tahanan melebihi dari volume yang ditetapkan dalam DIPA.

Bertambahnya narapidana dan tahanan di dalam Lembaga Pemasyarakatan pasti sangat berpengaruh terhadap penyedia bahan makanan dan narapidana, di mana jumlah anggaran yang telah dibuat selama 1 (satu) tahun tidak bertambah. Hal ini pasti membuat KPA dan penyedia harus mencari solusi dan untuk penyedia harus menyediakan anggaran tambahan untuk penambahan volume narapidana dan tahanan.

Kendala yang dihadapi oleh penyedia bahan makanan narapidana dan tahanan tidak hanya pada penambahan jumlah narapidana dan tahanan akan tetapi naik nilai harga di pasaran, sehingga harga jenis barang yang dilelang tidak sesuai lagi dengan harga di pasar, apalagi saat pemerintah mengumumkan kenaikan harga bahan bakar minyak maka harga setiap jenis barang dipasaran pasti akan terjadi kenaikan juga. Kenaikan harga jenis barang dipasaran penyedia juga harus menyediakan makanan untuk narapidana dan tahanan.

Bila dilihat dari jumlah anggaran yang disediakan memang untuk masing-masing narapidana dan tahanan di Lembaga Pemasyarakatan Kelas IIA Cibinong hanya sebesar Rp. 15.000,- (lima belas ribu rupiah), namun bila dijumlah dengan banyak narapidana dan tahanan untuk jumlah anggaran tersebut bisa menyediakan makanan yang berstandar gizi bagus.

Menurut Martin Roestamy, berkaitan dengan keadilan dalam Lembaga Pemasyarakatan, beliau menjelaskan beberapa contoh kesenjangan dalam Lapas, di mana orang yang memiliki jabatan serta uang mendapatkan fasilitas lebih di dalam
Lapas, namun napi biasa hidup berdesakan di dalam Lapas dengan keadaan yang sangat tidak manusiawi, beliau mengutip pernyataan dari pengacara senior berasal dari Medan, Mahyu Daniel, antara fasilitas dan negosiasi adalah perdagangan hantu tak dapat dilihat tetapi dapat dirasakan. Keadilan serta kesenjangan terjadi khususnya dalam rumah tahanan, sehingga beberapa kasus kematian seseorang di dalam rumah tahanan dianggap biasa, mungkin hal ini disebabkan karena sifat religiusitas masyarakat yang melihat kematian adalah milik Allah. Pengelolaan Lembaga Pemasyarakatan termasuk Rumah Tahanan khususnya kepolisian harus melihat masyarakat secara utuh tidak hanya sebagian berdasarkan negosiasi dan strata sosial sehingga fasilitas merupakan barang dagangan para sipir atau pejabat lebih tinggi. ${ }^{14}$

\section{KESIMPULAN}

Berdasarkan hasil penelitian di atas, maka penulis dapat mengambil kesimpulan:

1. Mekanisme pengadaan suplai makan tahanan Kepolisian Resort Bogor dan Lembaga Pemasyarakatan Cibinong Kelas IIA, telah berupaya memenuhi hak tahanan akan makanan sesuai peraturan standar minimum perlakuan terhadap tahanan yang berlaku dan Peraturan Menteri Hukum dan Hak Asasi Manusia Nomor M.HH01.PK.07.02 Tahun 2009 tentang Pedoman Penyelenggaraan Makanan Bagi Warga Binaan Pemasyarakatan di Lembaga Pemasyarakatan dan Rumah Tahanan Negara. Hal ini dapat terlihat dari penyediaan makanan yang tepat waktu dan disajikan tiga kali sehari oleh Kepolisian Resort Bogor dan

14"Fakultas Hukum Universitas Djuanda Bogor Bahas Perlindungan Kesehatan Bagi Tahanan Dalam Forum Group Discussion", https://unida.ac.id/post/detail/fakultas-hukumuniversitas-djuanda-bogor-bahas-perlindungankesehatan-bagi-tahanan-dalam-forum-groupdiscussion. Diakses tanggal 31 Juli 2019. 
Lembaga Pemasyarakatan Cibinong Kelas IIA walau pun dengan menu yang disajikan kurang bervariasi bila dilihat dari angka kecukupan gizi karena keterbatasan anggaran.

2. Pengadaan barang dan jasa di bidang makan tahanan Kepolisian dan Lembaga Pemasyarakatan untuk tercapainya keadilan, kewenangan Kuasa Pengguna Anggaran (KPA) pada saat proses pelelangan bahan makanan tahanan. Sehingga berdasarkan kewenangannya maka KPA pada Kepolisian Resort Bogor dan Lembaga Pemasyarakatan Cibinong Kelas IIA telah memanfaatkan kewenangannya pada saat proses pelelangan bahan makanan tahanan dilaksanakan, pengaturan hukum untuk keterlambatan saat memperoleh penyedia bahan makanan tahanan pada tahun anggaran berikutnya belum ada instrumen hukum yang jelas sehingga KPA Kepolisian Resort Bogor dan Lembaga Pemasyarakatan Cibinong Kelas IIA melakukan inisiatif sendiri dalam pengadaan bahan makanan tahanan.

\section{SARAN}

1. Ditjen Pemasyarakatan hendaknya dapat mengajukan usulan Perubahan Peraturan Menteri Hukum dan HAM Nomor M.HH-01.PK.07.02 Tahun 2009 tentang Pedoman Penyelenggaraan Makanan bagi Warga Binaan Pemasyarakatan di Lembaga Pemasyarakatan (Lapas) dan Rumah Tahanan Negara, agar penyelenggaraan makanan di Lapas sesuai dengan angka kecukupan gizi yang diterbitkan oleh Kementerian Kesehatan RI.

2. Kepada Kementerian Hukum dan HAM RI untuk dapat membuat aturan atau pedoman tentang adanya keterlambatan dalam memperoleh penyedia bahan makanan narapidana dan tahanan dan khusus kepada Lembaga Kebijakan Pengadaan Barang/Jasa (LKPP) untuk dapat memperbaharui aturan dalam Peraturan Presiden Nomor 16 Tahun 2018 dalam proses pelelangan barang/jasa pemerintah.

\section{DAFTAR PUSTAKA}

\section{Buku:}

Adrian Sutedi, Aspek Hukum Pengadaan Barang dan Jasa dan Berbagai Permasalahannya, Jakarta: Sinar Grafika, 2008.

Anggun Malinda, Perempuan dalam Sisten Peradilan Pidana (Tersangka, Terdakwa, Terpidana, Saksi, Korban), Yogyakarta: Garudhawaca, 2016.

Dwidja Priyatno, Sistem Pelaksanaan Pidana Penjara di Indonesia, Bandung: PT. Refika Aditama, 2006.

Endeh Suhartini dkk., Hukum Kesehatan Bagi Tahanan dan Warga Bianaan Pemasyarakatan di Indonesia, Depok: PT. RajaGrafindo Persada, 2019.

Jansen Selalahi, Makanan Fungsional, Yogyakarta: Kanisius, 2006. 
Martin Roestamy, dkk., Metode, Penelitian, Laporan dan Penulisan Karya Ilmiah Hukum Pada Fakultas Hukum, Program Studi Ilmu Hukum Universitas Djuanda, Bogor, 2015.

Miriam Budiarjo, Dasar-dasar Ilmu Politik, Jakarta: Penerbit PT Gramedia, 1980.

Muhammad Taufiq, Keadilan Substansial Memangkas Rantai Birokrasi Hukum, Cetakan I, Yogyakarta: Pustaka Pelajar, 2014.

Tiurma PT Simanjuntak, Tiurma, Komponen Gizi dan Terapi Pangan Ala Papua, Yogyakarta: Deepublish, 2014.

Yesmil Anwar dan Adang, Pembaruan Hukum Pidana, Reformasi Hukum Pidana, Jakarta: Grasindo, 2008.

\section{Peraturan Perundang-undangan}

Undang-undang Dasar Negara Republik Indonesia Tahun 1945.

Undang-undang Nomor 12 Tahun 1995 tentang Pemasyarakatan.

Undang-undang Nomor 36 Tahun 2009 tentang Kesehatan.

Peraturan Presiden Nomor 16 Tahun 2018 tentang Pengadaan Barang/Jasa Pemerintah.

Peraturan Menteri Hukum dan Hak Asasi Manusia Republik Indonesia Nomor: M.HH01.PK.07.02 Tahun 2009 tentang Pedoman Penyelenggaraan Makanan Bagi Warga Binaan Pemasyarakatan di Lembaga Pemasyarakatan dan Rumah Tahanan Negara.

\section{Jurnal Hukum}

Endeh Suhartini, Model Pelayanan Kesehatan Bagi Tahanan di Wilayah Hukum Bogor dan Cianjur Dalam Pencegahan Perluasan dan Penyalahgunaan Narkoba, Penelitian Unggulan Perguruan Tinggi, Universitas Djuanda Bogor, 2017.

Fence M. Wantu, "Mewujukan Kepastian Hukum, Keadilan dan Kemanfaatan Dalam Putusan Hakim di Peradilan Perdata”, Jurnal Dinamika Hukum, (Gorontalo) Vol. 12 Nomor 3, September 2012.

\section{Internet}

"Biaya Makan Tahanan di PPK Mahal", https://m.tempo.co/read/news/2014/03/12/063561591/biaya-makan-tahanandi-kpk-paling-mahal. Diakses pada tanggal 30 Desember 2018.

"Fakultas Hukum Universitas Djuanda Bogor Bahas Perlindungan Kesehatan Bagi Tahanan Dalam Forum Group Discussion", https://unida.ac.id/post/detail/fakultas-hukumuniversitas-djuanda-bogor-bahas-perlindungan-kesehatan-bagi-tahanan-dalamforum-group-discussion. Diakses tanggal 31 Juli 2019. 
"Menkumham Resmikan 13 Lapas Baru", http://www.hukumonline.com/berita/baca/lt553dc2454e2f9/menkumhamresmikan-13-lapas-baru. Diakses pada tanggal 30 Desember 2018.

"Napi Lapas Pondok Rajeg Kurus", http://aceh.tribunnews.com/2013/02/14/napi-lapaspondokrajeg-kurus. Diakses pada tanggal 30 Desember 2018.

\section{"Pelaksanaan} http://adtyadjavanet.blogspot.com/2013/11/pelaksanaan-pelayanankesehatan.html., Diakses pada tanggal 30 Desember 2018. 